\title{
Nanoparticles on the basis of polylactic acid and polylactic-co-glycolic acids loaded with drugs
}

\begin{abstract}
In this article a brief review on the research works devoted to the synthesis and investigation of polymeric nanoparticles and nanocapsules on the basis of polylactic acid and its copolymer with polyglycolic acid is given. Nanoparticles based on biocompatible and biodergadable polylactic acid and polylactic-co-glycolic acids gained special interest in pharmaceutical field as the carriers of different drug preparations. General methods of synthesizing nanosomal formulations of polylactic acid and polylactic-co-glycolic acids were described in this work. Among the perspective methods of obtaining the polymeric nanoparticles and nanocapsules of polylactides and its copolymer with glycolic acid loaded with drugs the nanoprecipitation and emulsion methods were found to be the most suitable for the systems used. Another method of synthesizing the nanosized systems of polylactic-co-glycolic acid is a double emulsion method which makes possible to obtain nanocapsules with optimal characteristics. The possibilities of immobilization of nanoparticulate systems based on these polymers with antitumor and antituberculosis drugs were considered. Some examples of polylactic acid and polylactic-co-glycolic acids' nanoparticles and nanocapsules loaded with drugs which have applications in medicine for the treatment of tumor and tuberculosis diseases were shown.
\end{abstract}

Keywords: polylactic acid, polylactic-co-glycolic acid, nanoparticles, antitumor drugs, antituberculosis drug, drug delivery, polymers, nanocapsules.

One of the promising drug carriers used in developing controlled drug delivery systems is polylactic acid (PLA) [1-13]. Polylactide or polylactic acid was first found in 1932 by Carothers. PLA was the first polymer which was used together with polygycolic acid as a surgical suture [1-6]. PLA is not soluble in water and in water-ethanol mixtures: it possesses unique properties including high mechanical properties and very low toxicity [2-13]. Polylactide is biocompatible and biodegradable polymer which has been used in medicine for a long time not only as an auxiliary material, but as carrier for the targeted delivery of the drugs [712]. First synthetic polymer and bioabsorbing material was polyglycolic acid which opened this class of polymers in 1954. Since that time the derivatives of this polymer with polylactic acid (polylactide) and $\varepsilon$ caprolactone have been used for the drug delivery purposes [13-15]. Incorporation of the chains of glycolic acid allows controlling the biodegradation rate, hence the drug release rate can be regulated by obtaining the copolymers of poly-lactic-co-glycolic acid (PLGA) of wide range of composition [16].

The drug delivery systems are known to be constructed on the basis of biocompatible polymers in the forms of micro- and nanoparticles or nanocapsules [13-20]. Biodegradable nanoparticles gained much interest of scientists due to their unique properties and advantages over conventional drug dosing forms. The use of such forms is especially important in a treatment of long-termed diseases using high doses of potent drugs. So, micro- and nanoparticles based on polylactic, polyglycolic acids and their copolymers and ethers, are used for the delivery of various drug preparations [13-27]. The polymers of glycolic and lactic acids are widely used for the preparation of biodegradable medical devices and of drug-sustained release microspheres or implants marketed in Europe, Japan, and the USA [27].

The use of the copolymers of lactic acid with glycolic acid gives more opportunities in the creation of controlled delivery systems for potent drugs which are used in the treatment of tumors and tuberculosis. Antitumor drug preparations based on nanoparticles of the copolymers of lactic and glycolic acids have been worked out and they are allowed to be used in medicine practice in Russian Federation by the trade names dekapeptyl, zoladex, sandostatin and somatulin [17]. The copolymer of lactic and glycolic [50/50 Poly-(D,Llactide-co-glycolide) (nominal)] acids is non-toxic and its catabolism in the organism ends up with the formation of $\mathrm{CO}_{2}$ and $\mathrm{H}_{2} \mathrm{O}[17,25,27]$.

Microspheres with controlled degradation were obtained on the basis of a copolymer of lactic and glycolic acids, polyethylene glycol (PEG) or polycaprolactam. An important feature of polylactides and polyglycolides is biocompatibility with the tissues of the body, enzymatic degradation by ethereal bonds to derivatives of lactic and glycolic acids. 
As it was mentioned above depending on the ratio of lactic and glycolic acids it is possible to change such properties of the product as plasticity, durability, the biodegradation time and release rate of the drug. It was found that varying the ratio of the lactic and glycolic chains the release rate of the drug can be controlled [28]. With increasing the content of glycolic chains the release rate of hydrophilic drugs increases and the release rate of lipophilic drugs decreases provided that the drug excretion takes place as a result of polymer degradation. By this way the copolymers of PLGA with PEG and poly- $\varepsilon$-caprolactone (PCL) with controlled degradability were successfully synthesized in [28]. They degrade by the ester bonds to the derivatives of lactic and glycolic acids. It has been established that polylactides with hydrophobic end groups degrades 2.7 times faster in vitro and 4 times faster in vivo than the polymers with hydrophilic groups [29].

Different techniques can be used for the preparation of nanostructures of PLA and PLGA:

- double emulsion followed by solvent evaporation [18, 19];

- dialysis [18, 19];

- nanoprecipitation [18-21];

- the salting out [19-24];

- supercritical fluid technology $[18,19]$.

Detailed description of these methods and the examples of the polymeric nanoparticles obtained using these techniques can be found in [18].

Among the effective and reproducible methods of obtaining nanoparticles of PLA, polyglycolic acid or their copolymers is found to be nanoprecipitation [18-30]. This method was first developed by Fessi et al. for the preparation of polymeric nanoparticles [19]. It is also called as solvent displacement method [19]. J. Prasad Rao and E. Geckeler Kurt described this process in detail [18]. According to them the basic principle of this technique is based on the interfacial deposition of a polymer after displacement of a semi-polar solvent, miscible with water, from a lipophilic solution [19]. Rapid diffusion of the solvent into non-solvent phase results in the decrease of interfacial tension between the two phases, which increases the surface area and leads to the formation of small droplets of organic solvent $[18,19]$. The authors inform that the nanoprecipitation system consists of three basic components: the polymer (synthetic, semi synthetic or natural), the polymer solvent and the non-solvent of the polymer [19]. Organic solvents such as ethanol, acetone, hexane, methylene chloride or dioxane which are miscible with water and easy to remove by evaporation can serve as a polymer solvent [19]. Due to this reason, acetone is the most frequently employed polymer solvent in this method [19]. Also there are some examples of using the solvent mixture (acetone-water, acetoneethanol and methanol) [19]. J. Prasad Rao and Kurt E. Geckeler summarized the examples of the polymers, solvents and non-solvents used for the preparation of nanoparticles by nanoprecipitation method in Table 1 [18].

Ta b l e 1

Nanoprecipitation formulations for the preparation of polymer nanoparticles [18]

\begin{tabular}{|l|c|c|c|c|c|}
\hline \multicolumn{1}{|c|}{ Polymer } & Solvent & $\begin{array}{c}\text { Non- } \\
\text { solvent }\end{array}$ & Stabilizing agent & $\begin{array}{c}\text { Particle size, } \\
\text { nm }\end{array}$ & References \\
\hline PLGA & Acetone & Water & PVA & $95-560$ & {$[24]$} \\
Allylic starch & Acetone & Water & - & 270 & {$[16]$} \\
Dextran ester & Acetone & Water & - & 77 & {$[27]$} \\
PLGA & Acetone/ethanol & Water & Tween 20 & $63-90$ & {$[31]$} \\
PCL diol & Chloroform & Water & Pluronic F 127 & 17.4 & {$[16]$} \\
Eudragit L100-155 & Acetone/absolute ethanol & Water & - & 120 & {$[22]$} \\
PLGA & Acetone & Water & - & $165 \pm 5$ & {$[27]$} \\
& Acetonitrile & & & $164 \pm 4$ & {$[23]$} \\
PCL & Acetone & Water & PVA & $365 \pm 5$ & \\
PLA & THF & Water & - & $100-300$ & {$[24]$} \\
PCL & Acetone & Water & - & $741-924$ & {$[21]$} \\
PCL & Acetone & Water & Span 20 & $266 \pm 11$ & {$[20]$} \\
PLA & Acetone & Water & Polysorbate 80 & $250 \pm 50$ & {$[25]$} \\
PCL & Acetone & Water & Poloxamer 188 & $308-352$ & {$[20]$} \\
& & & PE/F68 & & {$[27]$} \\
\hline
\end{tabular}


According to H. Fessi, et al. [19] when obtaining nanoparticles using nanoprecipitation method the process of particle formation consists of three stages: nucleation, growth and aggregation. The rate of each step determines the particle size and the driving force of these phenomena is the ratio of polymer concentration over the solubility of the polymer in the solvent mixture [19]. The separation between the nucleation and the growth stages is the key factor for uniform particle formation.

The system of nanoprecipitation mainly consists of three components; these are the polymer, the solvent of the polymer and non-solvent of the polymer [18, 19]. PLA nanoparticles with the range of particle size from 100 to $300 \mathrm{~nm}$ were obtained depending on the solvent and surfactant used in [19,21]. So nanoprecipitation is a simple, fast and reproducible method which allows obtaining both nanoparticles and nanocapsules [18].

PLGA nanoparticles coated with transferrin with the size in the range $63-90 \mathrm{~nm}$ for the purpose of passing through blood-brain-barrier were successfully synthesized in the presence of Tween 20 using nanoprecipitation method [22]. B.J. Nehilla et al. synthesized coenzyme Q10-loaded PLGA nanoparticles without using surfactant with the average size $165 \mathrm{~nm}$ [23]. Nanoprecipitation method was also used for the encapsulation of curcumin into PLGA nanoparticles by M.M. Yallapu et al. [24] as a result of which the particles with the size ranging in 95-560 nm were obtained.

The mechanism of intracellular uptake of PLGA nanoparticles and their effect on therapeutic efficiency of the active compounds in cellular level when encapsulating DNA, proteins and different low molecular weight compounds are throhoughly considered by J. Panyam and V. Labhasetwar in [16].

There are also the examples of using PLA and PLGA nanoparticles for the treatment of tumor and tuberculosis diseases below.

Derakhshandeh K. et al. encapsulated 9-nitrocamphotericin in the copolymer of poly-lactic-co-glycolic acids using above said nanoprecipitation method. As a result the encapsulation efficiency $30 \%$ [11]. Fonseca C. with colleagues synthesized PLGA nanoparticles loaded with Paclitaxel using solvent evaporation followed by extraction [12]. In this case the authors achieved the encapsulation efficiency of $100 \%$ with complete maintenance of antitumor activity in in vitro study [31]. In [30] PLGA nanospheres immobilized with triptorelin were synthesized using the double emulsion technique followed by solvent evaporation. As a result the encapsulation efficiency varied from 4 to $83 \%$ depending on initial drug concentration [30]. The authors of the work [31] successfully encapsulated poorly water-soluble xantones into PLGA nanoparticles.

Helle A. et al. investigated the possibility of using capillary electrophoresis for the quantitative determination of model drugs (salbutamol sulphate, sodium chromoglycate and beclomethasone dipropionate) which were encapsulated in PLA nanoparticles by nanoprecipitation method [26]. A quantitative capillary electrophoresis method was developed for salbutamol sulphate and sodium chromoglycate by the authors. It was found out that the encapsulation of beclomethasone dipropionate in the PLA nanoparticles was more efficient than in case of more hydrophilic model drugs (salbutamol sulphate and sodium chromoglycate) [26].

It is necessary to note that there are works on obtaining nanoparticles from the commercial polymers and load them with drugs. For instance, Jae-Woon Nah et al. prepared nanoparticles of PLGA using dialysis method without surfactant [32] and loaded them with a model drug clonazepam. The authors investigated the effect of different solvents on physicochemical characteristics of the nanoparticles and found that the drugloading contents were dependent on the copolymer composition and initial feeding amount of the drug [32].

R. Jalil and J.R. Nixon prepared the microcapsules of PLA containing phenobarbitone using a w/o emulsion-evaporation method [33]. The authors used the polymer of three different molar masses, 20.200, 13.300 and 5.200 to obtain microcapsules and they studied the in vitro release kinetics of phenobarbitone from prepared microcapsules at different $\mathrm{pH}$ values $(\mathrm{pH} \mathrm{2,} \mathrm{pH} 7$ and $\mathrm{pH} 9)$ [34]. They have found that the release follows in a square root of time dependent release mechanism [34]. M. Dutt, et al. used the same technique to obtain PLGA microparticles and load them with the antiTB drugs isoniazid and rifampicin. It resulted in PLGA nanoparticles with the drugs with the size around 200-300 $\mathrm{nm}$ and with the encapsulation efficiency of 50-65\% [35]. The authors investigated the in vitro and in vivo drug release on CaCo-2 cells and established that obtained nanoparticles had a slower release kinetics compared to free drugs [35].

During the last decades various polymeric systems have been developed for the targeted delivery of antitumor drug preparations. The examples of nanoparticles on the basis of PLA and PLGA, PEG-PLGA for passive transport of antitumor drugs are given in Table 2 [36]. 
Table 2

Polymeric nanoparticles developed for the delivery of drugs to treat various tumors [36]

\begin{tabular}{|c|c|c|c|c|}
\hline Polymer & Drug & Tumor cell line & $\begin{array}{l}\text { In vitro and in } \\
\text { vivo study }\end{array}$ & References \\
\hline \multirow{5}{*}{ PLGA } & Paclitaxel & Human cervical carcinoma cells (HeLa) & $\begin{array}{c}\text { In vitro } \\
\text { and in vivo }\end{array}$ & 37 \\
\hline & Cisplastin & Colon adenocarcinoma cells & $\begin{array}{l}\text { In vitro and in } \\
\text { vivo in mice }\end{array}$ & 38,39 \\
\hline & 5-Fluorouracil & $\begin{array}{c}\text { Glioma (U87MG) and breast and } \\
\text { adenocacinoma (MCF-7) cell lines }\end{array}$ & In vitro & 40 \\
\hline & Doxorubicin & $\begin{array}{l}\text { MDA-MB-231 breast tumor cells } \\
\text { HeLa cells } \\
\text { Fibroblust cells } \\
\text { Lung epithelial tumor cells (A549) }\end{array}$ & $\begin{array}{l}\text { In vitro } \\
\text { In vitro } \\
\text { In vitro } \\
\text { In vitro }\end{array}$ & $\begin{array}{l}41 \\
42 \\
43 \\
44\end{array}$ \\
\hline & Gemcitabine & Pancreatic tumor cells (PANCl) & In vitro & 45 \\
\hline PLGA-mPEG & Cisplastin & Prostate tumor $(\mathrm{LNCaP})$ cells & In vitro & 46 \\
\hline \multirow{2}{*}{ PLGA-b-PEG } & Docetaxel & Prostate tumor (LNCaP) cells & $\begin{array}{c}\text { In vivo in nude } \\
\text { mice }\end{array}$ & 47 \\
\hline & Cisplastin & $\begin{array}{l}\text { Breast (MCF-7) and prostate tumor (PC-3 } \\
\text { and DU145) cells }\end{array}$ & $\begin{array}{c}\text { In vitro and in } \\
\text { vivo in nude mice }\end{array}$ & 48 \\
\hline $\begin{array}{l}\text { PLGA-mPEG+ } \\
\text { carboxymethyl } \\
\text { cellulose }\end{array}$ & Cisplastin & Ovarian tumor (IGROVI-CP) cells & $\begin{array}{c}\text { In vitro and in } \\
\text { vivo in mice }\end{array}$ & 49 \\
\hline $\begin{array}{l}\text { hyaluronic acid- } \\
\text { PEG-PLGA }\end{array}$ & 5-Fluorouracil & EAT cell lines & $\begin{array}{l}\text { In vitro and in } \\
\text { vivo in mice }\end{array}$ & 50 \\
\hline $\begin{array}{l}\text { 1-PLGA-human } \\
\text { serum albumin }\end{array}$ & Doxorubicin & Rat glioblastoma & In vivo in rat & 51 \\
\hline
\end{tabular}

Isoniasid is a first-line drug to treat tuberculosis which can be administered perorally as well as intramuscularly. However the drug dose used for healing the disease is high compared to the required minimum inhibitory concentration of the drugs [52]. Therefore the attention of scientists is concentrated on prolongation the effect of isoniazid together with other antiTB drug preparations by encapsulation them in different matrices. M.Zh. Burkeev et al. used the same method (nanoprecipitation) for the encapsulation of widely used antituberculosis drugs isoniasid and p-aminosalicylic acid (PASA) in PLA and PLGA nanoparticles [53]. Optimal conditions (solvent, the ratio polymer: drug, etc.) for synthesizing PLA nanocapsules loaded with the drugs were found. The best results were obtained when acetone was used as a solvent. Nanoparticles of PLA loaded with isoniazid with the average diameter 200-300 $\mathrm{nm}$ and high meaning of binding degree $(50 \%)$ have been successfully synthesized. Immobilization of PLA nanoparticles with antituberculosis drug isoniazid have been performed with the ratio of the polymer to drug as 1:10, 1:5, 1:4. As a result of the experiments the last proportion was chosen as an optimal one. The procedure can be described briefly as follows: $5 \mathrm{mg}$ of drug was dissolved in $0.2 \mathrm{ml}$ of water and then $0.5 \mathrm{ml}$ of acetone was added. $20 \mathrm{mg}$ of PLA was dissolved in $1 \mathrm{ml}$ of acetone and was mixed with the solution containing the drug. After that organic solvent was evaporated within $40 \mathrm{~min}$ at low pressure. The volume of the dispersion was made to $20 \mathrm{ml}$ with water and filtered from aggregated particles. Obtained nanoparticles were characterized using photon correlation spectroscopy which have shown that the system consists of rather small particles with the size 253.7 $\mathrm{nm}$ and obtained particles have narrow particle size distribution $(\mathrm{PDI}=0.241)$. The yield of PLA nanoparticles with isoniazid was $78.4 \%$. The system was found to be stable within the time which was confirmed by measurement of the surface charge of nanoparticles $(-30-35 \mathrm{mV})$ [53].

PASA and its sodium salt are commonly used in tuberculosis therapy together with aminoglycosides. It is specifically to treat active drug resistant tuberculosis. Having high activity against strains of Mycobacterium tuberculosis it has side effects typical to antituberculosis drug preparations, which needs to be reduced. Therefore with the aim of increasing the efficiency of this drug and decreasing its therapeutic concentration the possibility of binding antituberculosis drug PASA with PLA nanoparticles was studied further by our research group. Data on physicochemical characteristics of synthesized empty PLA nanoparticles and polymeric particles loaded with antituberculosis drugs isoniazid and PASA are summarized in Table 3. 
Physicochemical characteristics of empty and drug loaded PLA nanoparticles

\begin{tabular}{|c|c|c|c|c|}
\hline \multirow{2}{*}{\multicolumn{2}{|c|}{ Characterization of nanoparticles }} & \multirow{2}{*}{$\begin{array}{c}\text { Empty PLA } \\
\text { nanoparticles }\end{array}$} & \multicolumn{2}{|c|}{ PLA nanoparticles loaded with drugs } \\
\hline & & & with isoniazid & with PASA \\
\hline \multicolumn{2}{|c|}{ Average particle diameter, $\mathrm{d}, \mathrm{nm}$} & 290.1 & 253.7 & 310.7 \\
\hline \multicolumn{2}{|l|}{ PDI } & 0.316 & 0.241 & 0.515 \\
\hline \multicolumn{2}{|c|}{ Zeta potential, $\mathrm{mV}$} & -35.0 & -30.4 & -32.6 \\
\hline \multicolumn{2}{|c|}{ Fraction of nanoparticles, $\%$} & 98.8 & 97.5 & 100.0 \\
\hline \multicolumn{2}{|c|}{ Yield of nanoparticles, \% } & 76.6 & 78.4 & 76.0 \\
\hline \multirow{2}{*}{ Binding $(\%)$} & conductometry & - & 50.5 & 68.7 \\
\hline & spectrophotometry & - & - & 70.4 \\
\hline
\end{tabular}

From data given in Table 3 it is obvious that the particle size (determined by dynamic light scattering (DLS) of PLA nanoparticles increased after incorporation of the drug which probably took place because of the adsorption of some part of the PASA on the surface of PLA nanoparticles. The yields of the nanoparticles with and without drug (determined using gravimetry) were high in both cases (Table 3). Data on binding obtained by two methods (conductometry and spectrophotometry) show that the meanings of binding degree of PASA with PLA nanoparticles correlates with each other and equal to $68.7 \%$ and $70.4 \%$ accordingly.

Poor solubility of some potent drugs in water is one of the major obstacles in using such drug preparations. In this regard the scientific group under supervision of prof. M.Zh. Burkeev investigated the possibility of loading the nanoparticles on the basis of PLA and PLGA with poorly-water soluble drug silymarin. Silymarin is known to be a potent antioxidant, liver protector and anti-cancer agent. Its hepatoprotective effectiveness is due to its antioxidant and anti-inflammatory properties. Being such an effective drug it has a problem of low bioavailability caused by its poor solubility in water, which means that high dose of the drug is needed for achieving therapeutic level in plasma. Its solubility in distilled water is $58 \mathrm{mkg} / \mathrm{ml} \mathrm{at} 25^{\circ} \mathrm{C}$, therefore this drug is considered as a preparation insoluble in water [54]. With the aim of synthesizing novel form of silymarin which provides sustained release Y. Ma et al. encapsulated it in self-assembled nanoparticles of Bletilla striata polysaccharide conjugates modified with stearic acid [54, 55]. Obtained nanoparticles of a mean diameter of $200 \mathrm{~nm}$ exhibited a sustained-release profile for nearly 1 week with no obvious initial burst and they showed a lower viability and higher uptake intensity on HepG2 cell lines compared to drug solutions [55].

With the aim of overcoming low bioavailability of silymarin the attempts to bind this drug with PLA nanoparticles was made by our research group. Nanoparticles of PLA loaded with silymarin were synthesized using nanoprecipitation method. As a result PLA nanoparticles containing the drug with the mean diameter $206.9 \mathrm{~nm}$ and PDI 0.291 were obtained. To observe the surface of the drug-loaded PLA nanoparticles they were analyzed using electron microscopy (SEM and REM). The images of PLA nanoparticles immobilized with silymarin are shown in Figure.

From given pictures it is seen that the system is not stable at a time and the particles have aggregated; however there are separate nanoparticles the meaning of mean diameter of which is in good accordance with data obtained by DLS. The binding degree of PLA with the drug determined using UV-Vis-spectroscopy $(\lambda=325 \mathrm{~nm})$ was $75 \%$ which is a high value.

The nanoparticles on the basis of PLGA can be obtained by various methods: by mixing aqueous and organic solvents containing polymer and drug substance and then removing first the organic and then the aqueous phase [18, 19, 56-64]. The methods for obtaining nanoparticles are based on the ability to form films at the water/solvent interface. Thus, with intensive mixing of the polymer solution in chloroform or methylene chloride with a small amount of water, particles with a polymer shell containing water or a solution of the drug substance are formed. When the water: solvent ratio is reversed, it is possible to obtain nanoparticles with a solvent incorporated therein.

Most of the methods used to incorporate active substances into the polymer matrix are based on the use of emulsions. The method of obtaining nanoparticles using emulsions consists in dispersing and stabilizing one liquid by another, in which it is insoluble. The key criterion for creating an emulsion is the insolubility (or weak solubility) of the dispersed phase in a homogeneous dispersion medium. Further, the resulting emulsion is mixed with a surfactant solution and the solvent and water are removed. 
a)

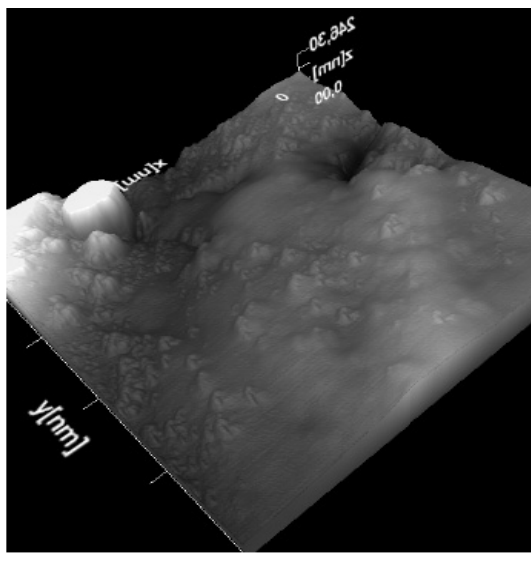

)

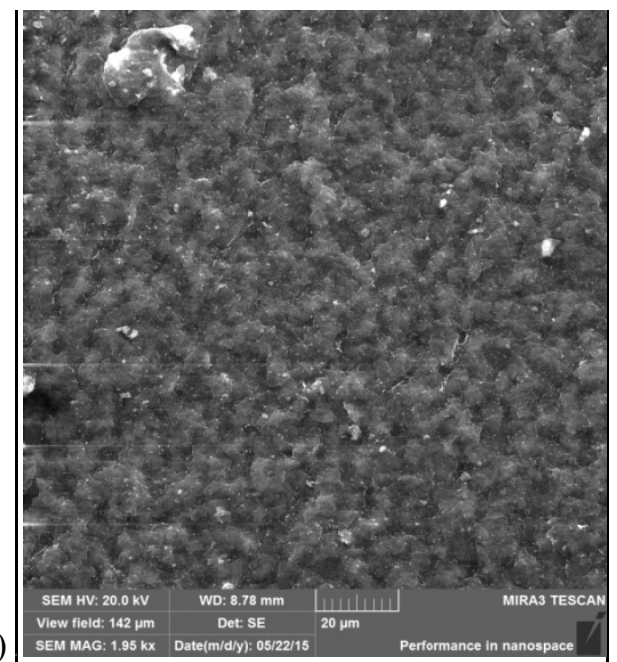

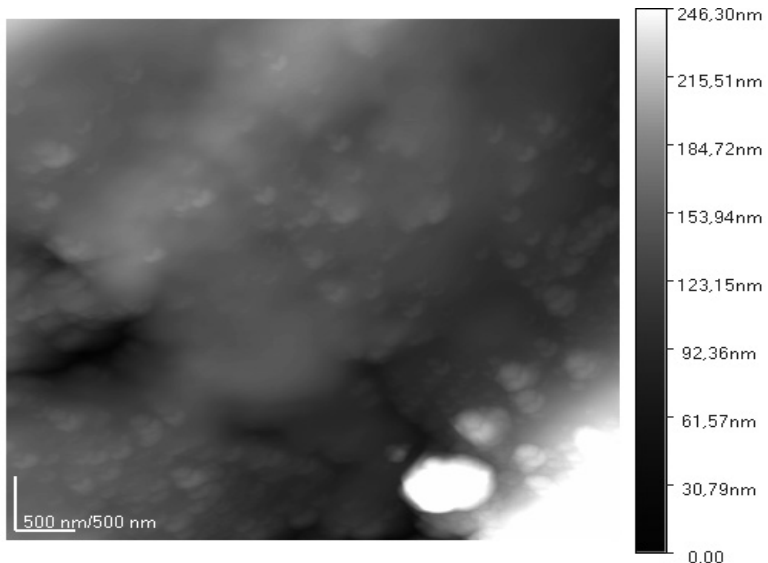

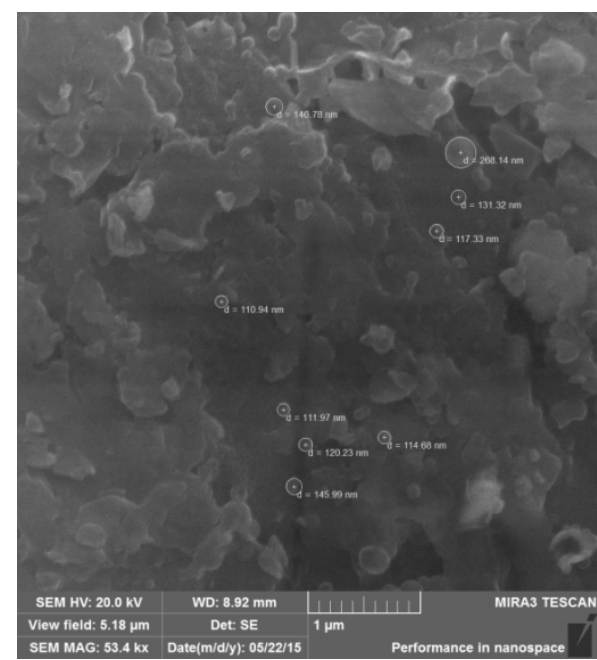

Figure. SEM ( $a$ ) and REM $(b)$ images of PLA nanoparticles loaded with silymarin

In this regard the attempts to immobilize the antituberculosis drug p-aminosalicylic acid into the polymer matrix of PLGA using the emulsion method were made by our research group. The ratio of 1:8 of the drug to the polymer and the concentration of surfactant $5 \%$ (polyvinyl alcohol) were found to be optimal for synthesizing nanoparticles with satisfactory characteristics and with high meaning of binding degree (78 \%).

\section{Conclusions}

Advances of nanotechnology in medicine, especially in the field of applying nanoparticulate systems for the controlled drug delivery are obvious. Nowadays there are the systems which have already passed preclinical and clinical trials and are allowed to be used in therapy of different tumors and tuberculosis diseases.

The review on the use of PLA and PLGA as drug carriers for the last two decades shows the increase of the number of publications in this area; hence the works on synthesizing nanoparticles and nanocapsules on the basis of these polymers for the drug delivery purposes are gaining much interest. The results of the studies points on the importance and potential of application of such systems on the basis of PLA and its copolymer with glycolic acid in the treatment of long-termed diseases such as tumors and tuberculosis.

The review given in this article is far from being comprehensive, however the authors tried to cover all aspects of synthesizing and characterization of nanoparticulate systems on the basis of such polymers as PLA and PLGA loaded with drugs.

\section{References}

1 Okada, M. (2002). Chemical synthesis of biodegradable polymers. Prog. Polym. Sci., 27, 87-133.

2 Qiu, L.Y, \& Bae, Y.H. (2006). Polymer architecture and drug delivery. Pharm. Res., 23(1), 1-30.

3 Drumright, R.E., Gruber, P.R., \& Henton, D.E. (2000). Polylactic acid technology. Advanced Materials, 12(23), $1841-1846$.

4 Dechy-Cabaret, O., Martin-Vaca, B., \& Bourissou, D. (2004). Controlled ring-opening polymerization of lactide and glycolide. Chemical Reviews., 104(12), 6147-6176. 
5 Kricheldorf, H.R., \& Kreiser-Saunders, I. (1996). Polylactides - synthesis, characterization and medical application. Macromolecular Symposia, 103, 85-102.

6 Vert, M. (2000). Lactide polymerization faced with therapeutic application requirements. Macromolecular Symposia, 153, $333-342$.

7 Slomkovski, S. (2006). Biodegradable nano- and microparticles as carriers of bioactive compounds. Acta Pol. Pharm., 63(5), $351-358$.

8 Nair, L.S., \& Laurencin, C.T. (2007). Biodegradable polymers as biomaterials. Prog. Polym. Sci., 32, 762-789.

9 Mehta, R., Kumar, V., Bhunia, H., \& Upadhyay, S.N. (2005). Synthesis of poly(lactic acid): a review. J. Macromol. Sci. Polym. Rev., 45, 325-49.

10 Dorgan, J.R., Lehermeier, H., \& Mang, M. (2000). Thermal and rheological properties of commercial-grade poly(lactic acids)s. J. Polym. Environ., 8, 1-9.

11 Derakhshandeh, K., Erfan, M., \& Dadashzadeh, S. (2007). Encapsulation of 9-nitrocamptothecin, a novel anticancer drug, in biodegradable nanoparticles: factorial design, characterization and release kinetics. Eur. J. Pharm. Biopharm., 66(1), 34-41.

12 Fonseca, C., Simoes, S., \& Gaspar, R. (2002). Paclitaxel-loaded PLGA nanoparticles: preparation, physicochemical characterization and in vitro anti-tumoral activity. J. Control. Rel., 83(2), 273-286.

13 Avgoustakis, K., Beletsi, A., \& Panagi, Z., et al. (2002). PLGA-mPEG nanoparticles of cisplatin: in vitro nanoparticle degradation, in vitro drug release and in vivo drug residence in blood properties. J. Control. Rel., 79(1-3), 123-35.

14 Gao, H., Wang, Y.N., \& Fan, Y.G., et al. (2005). Synthesis of a biodegradable tadpole-shaped polymer via the coupling reaction of polylactide onto mono(6-(2-aminoethyl)amino-6-deoxy)-beta-cyclodextrin and its properties as the new carrier of protein delivery system. J. Control. Rel., 107(1), 158-73.

15 Avgoustakis, K. (2004). Pegylated poly(lactide) and poly(lactide-coglycolide) nanoparticles: preparation, properties and possible applications in drug delivery. Curr. Drug Deliv., 1(4), 321-333.

16 Panyam, J., \& Labhasetwar, V. (2003). Biodegradable nanoparticles for drug and gene delivery to cells and tissue. Adv. Drug Del. Reviews, 55, 329-47.

17 Charles, E.L., \& Buffalo, N.Y. (1954). United States patent No. US 3297033. Preparation Method of Poly-(D,L-lactide-coglycolide) Nanoparticles with drugs.

18 Prasad Rao J., \& Geckeler Kurt E. (2011). Polymer Nanoparticles: Preparation techniques and size control parameters. Progr. Polymer Sci., 36, 887-913.

19 Fessi, H., Puisieux, F., \& Devissaguet, J.P., et al. (1989). Nanocapsule formation by interfacial polymer deposition following solvent displacement. Int. J. Pharm., 55, $1-4$.

20 Seyler, I., Appel, M., \& Devissaguet, J.P., et al. (1999). Macrophage activation by a lipophilic derivative of muramyldipeptide within nanocapsules: investigation of the mechanism of drug delivery. J. Nanopart. Res., 1, 91-97.

21 Legrand, P., Lesieur, S., \& Bochot, A., et al. (2007). Influence of polymer behaviour in organic solution on the production of polylactide nanoparticles by nanoprecipitation. Int. J. Pharm., 344, 33-43.

22 Chang, J., Jallouli, Y., \& Kroubi, M., et al. (2009). Characterization of endocytosis of transferrin-coated PLGA nanoparticles by the blood-brain barrier. Int. J. Pharm., 379, 285-292.

23 Nehilla, B.J., Bergkvist, M., \& Popat, K.C., et al. (2008). Purified and surfactant-free coenzyme Q10-loaded biodegradable nanoparticles. Int. J. Pharm., 348, 107-114.

24 Yallapu, M.M., Gupta, B.K., \& Jaggi, M., et al. (2010). Fabrication of curcumin encapsulated PLGA nanoparticles for improved therapeutic effects in metastatic cancer cells. J. Colloid. Interface Sci., 351, 19-29.

$25 \mathrm{Li}, \mathrm{H}$., Tran, W., \& Hu, Y., et al. (2006). A PEDF N-terminal peptide protects the retina from ischemic injury when delivered in PLGA nanospheres. Exp. Eye Res., 83(4), 824-833.

26 Helle, A., Hirsjarvi, S., \& Peltonen, L., et al. (2008). Quantitative determination of drug encapsulation in poly(lactic acid) nanoparticles by capillary electrophoresis. J. Chromatography. A., 1178, 248-55.

27 Moghimi, S.M., Hunter, A.C., \& Murray, J.C. (2005). Nanomedicine: current status and future prospects. FASEB J., 19, 311322.

28 Fenske, D.B., Chonn, A., \& Cullis, P.R. (2008). Liposomal nanomedicines: an emerging field. Toxicol. Pathol., 36(1), 21-29.

29 Shaitan, K., Tourleigh, Y., \& Golik, D., et al. (2006). Computer-aided molecular design of nanocontainers for inclusion and targeted delivery of bioactive compounds. J. Drug Del. Sci. Tech., 16, 253-258.

30 Nicoli, S. (2001). Design of triptorelin loaded nanospheres for transdermal iontophoretic administration. Int. J. Pharm., 214 (1-2), 31-35.

31 Pinto, M.M., \& Sousa, E.P. (2003). Natural and synthetic xanthonolignoids: chemistry and biological activities. Curr. Med. Chem., 10(1), 1-12.

32 Nah, J.-W., Young, J.J., \& Koh, J.-J. (2000). Drug release from nanoparticles of poly-D,L-lactide-co-glycolide. Korean J. Chem. Eng., 17(2), 230-236.

33 Jalil, R., \& Nixon, J.R. (1990). Microencapsulation using poly-D, L-lactic acid III: Effect of polymer molecular weight on the release kinetics. J. Microencapsulation, 7(3), 357-374.

34 Jalil, R., \& Nixon, J.R. (1990). Microencapsulation using poly-D,L-lactic acid IV: Effect of storage on the microcapsules' characteristics. J. Microencapsulation, 7(3), 375-383.

35 Dutt, M., \& Khuller, G.K. (2001). Chemotherapy of Mycobacterium tuberculosis infections in mice with a combination of isoniazid and rifampicin entrapped in poly(D,L-lactide-co-glycolide) microparticles. Journal of Antimicrobial Chemotherapy, 47, 829-835.

36 Prabhu, R.H., Patravale, V.B., \& Joshi, M.D. (2015). Polymeric nanoparticles for targeted treatment in oncology: Current Insights. International Journal of Nanomedicine, 10, 1001-1018. 
37 Danhier, F., Lecouturier, N., \& Vroman, B., et al. (2009). Paclitaxel-loaded PEGylated PLGA-based nanoparticles: in vitro and in vivo evaluation. J. Control. Rel., 133(1), 11-17.

38 Moreno, D., de Hardaya, C.T., \& Bandries, E., et al. (2008). Characterization of cysplastin toxicity delivered from PLGAsystems. Eur. J. Pharm. Biopharm., 68(3), 503-512.

39 Moreno, D., Zalba, S., \& Navarro, I., et al. (2010). Pharmacodynamics of cysplastin-loaded PLGA nanoparticles adminestered to tumor-bearing mice. Eur. J. Pharm. Biopharm., 74(2), 265-274.

40 Nair, K.L., Jagadeeshan, S., Nair, S.A., \& Kumar, G.S. (2011). Biological evaluation of 5-fluororacil nanoparticles for cancer therapy and its dependence on the carrier, PLGA. Int. J. Nanomed., 6, 1685-1697.

41 Betancourt, T., Brown, B., \& Brannon-Peppas, L. (2007). Doxorubicin-loaded PLGA nanoparticles by nanoprecipitation: preparation, characterization and in vitro evaluation. Nanomed., 2(2), 219-232.

42 Park, H., Yang, J., \& Lee J., et al. (2009). Multifunctional nanoparticles for combined doxorubicin and photothermal treatments. ACS Nano., 3(10), 2919-2926.

43 Amjadi, I., Rabiee, M., \& Hosseini, M.S., et al. (2012). Synthesis and characterization of doxorubicin-loaded PLGA nanoparticles as a sustained release anticancer drug delivery system. Appl. Biochem. Biotech., 168(6), 1434-1447.

44 Chittasupho, C., Xie, S.X., \& Baoum, A., et al. (2009). ICAM-1 targeting of doxorubicin-loaded PLGA nanoparticles to lung epithelial cells. Eur. J. Pharm., 37(2), 141-150.

45 Aggarwal, S., Yadav, S., \& Gupta S. EGFR targeted PLGA nanoparticles using gemcitabine for treatment of pancreatic cancer. J. Biomed. Nanotechnol., 7(1), 137-138.

46 Gryparis, E.S., Hatziapostolou, M., \& Paradimitriou E., et al. (2007). Anticancer activity of ciplastin-loaded PLGA-mPEG nanoparticles on LNCaP prostate cancer cells. Eur.J. Pharm. Biopharm., 67(1), 1-8.

47 Cheng, J., Teply, B.A., \& Sherifi, I., et al. (2007). Formulation of functionalized PLGA-PEG nanoparticles for in vivo targeted drug delivery. Biomaterials., 28(5), 869-876.

48 Graf, N., Bielenberg, D.R., \& Kolishetti, N., et al. (2012). $\alpha(V) \beta(3)$ Integrin-targeted PLGA-PEG nanoparticles for enhanced antitumor efficiency of a Pt (IV) prodrug. ACS Nano., 6(5), 4530-4539.

49 Cheng, L., Jin, C., \& Lu, W., et al. (2011). Developing a highly stable PLGA-mPEG nanoparticle loaded with cisplastin for chemotherapy of ovarian cancer. PLoS One., 6(9), 425-433.

50 Yadav, A.K., Agarwal, A., \& Rai G., et al. (2010). Development and characterization of hyaluronic acid decorated PLGA nanoparticles for delivery of 5-fluororacil. Drug. Del., 17(8), 561-572.

51 Wohlfart, S., Khalansky, A.S., \& Gelperina, S., et al. (2011). Efficient chemotherapy of rat glioblastoma using doxorubicin loaded PLGA nanoparticles with different stabilizers. PLoS One., 6(5), 119-121.

52 Bui, K.T., \& Alyautdin, R.N. (2008). Polylactide nanoparticles with antituberculosis drugs adsorbed on them. Exp. Clin. Pharmacology, 3, 7-11.

53 Burkeev, M.Zh., Tazhbayev, Ye.M., Zhaparova, L.Zh., Zhumagalieva, T.S., \& Zhappar, N.K. (2016). Synthesis and characterization of poly(DL-lactic acid) nanoparticles loaded with the antituberculosis drug Isoniazid. Pharm. Chem. J., 50(9), 608-612.

54 Ma, Y., He, S., \& Ma, X., et al. (2016). Silymarin-loaded nanoparticles based on stearic acid-modified Bletilla striata polysaccharide for hepatic targeting. Biomed. Pharmacotherapy, 81, 93-103.

55 Kwan, Y. Y., Du, H. H., \& Yousaf, A. M., et al. (2013). Silymarin-loaded solid nanoparticles provide excellent hepatic protection: physicochemical characterization and in vivo evaluation. Int. J. Nanomed., 8, 3332-3343.

56 Quintanar-Guerrero, D., Allémann, E., Doelker, E., \& Fessi, H. (1997). A mechanistic study of the formation of polymer nanoparticles by the emulsification-diffusion technique. Colloid Polym. Sci., 275, 640-647.

57 Quintanar-Guerrero, D., Allémann, E., Doelker, E., \& Fessi, H. (1996). Influence of stabilizing agents and preparative variables on the formation of poly(lactic acid) nanoparticles by an emulsification-diffusion technique. Int. J. Pharm., 143, $133-141$.

58 Allémann, E., Gurny, R., \& Doelker, E. (1993). Drug loaded nanoparticles. Preparation, methods and drug targeting issues. Eur. J. Pharm. Biopharm., 39, 173-191.

59 Gurny, R., Peppas, N.A., Harrington, D.D., \& Banker, G.S. (1981). Development of biodegradable and injectable lattices for controlled release potent drugs. Drug. Dev. Ind. Pharm., 7, pp. 1-25.

60 Allémann, E., Gurny, R., \& Doelker, E. (1992). Preparation of aqueous polymeric nanodispersions by a reversible salting-out process: influence of process parameters on particle size. Int. J. Pharm., 87(1-3), 247-253.

61 Dong, W.Y., Körber, M., López Esguerra, V., \& Bodmeier, R. (2006). Stability of poly(D,L-lactide-co-glycolide) and leuprolide acetate in in-situ forming drug delivery systems. J. Control. Release, 115(2), 158-167.

62 Delie, F., Berton, M., Allémann, E., \& Gurny, R. (2001). Comparison of two methods of encapsulation of an oligonucleotide into poly(D,L-Lactic Acid) particles. Int. J. Pharm., 214, 25-30.

63 Bilati, U., Allémann, E., \& Doelker, E. (2005). Poly(D, L-lactide-coglycolide) protein-loaded nanoparticles prepared by the double emulsion method - processing and formulation issues for enhanced entrapment efficiency. J. Microencapsul., 22(2), 205214.

64 Olivier, J.-Ch. (2005). Drug Transport to Brain with Targeted Nanoparticles. J. Amer. Soc. for Exp. Neurotherapeutics, 2 , $108-119$. 


\title{
Е.М. Тажбаев, М.Ж. Буркеев, Л.Ж. Жапарова, Т.С. Жұмағалиева, Ж.Т. Арыстанова
}

\section{Дәрілік заттармен иммобилизацияланған полисүт қышқылы мен полилактидгликолид негізіндегі нанобөлшектер}

\begin{abstract}
Мақалада полисүт қышқылы мен оның гликоль қышқылымен сополимерінің негізінде полимерлі нанобөлшектер мен нанокапсулаларды алуға бағытталған зерттеу жұмыстарына қысқаша шолу жасалған. Биоүйлесімді және биоыдырамалы полисүтқышқылы мен полилактидгликолид қышқылы полимерлерінің нанобөлшектері фармацевтика саласында дәрілік заттардың тасымалдаушылары ретінде ғалымдардың назарын ерекше аударып отыр. Авторлар полилактид және полилактидгликолид қышқылдарының наноөлшемді үлгілерін алу әдістерін сипаттаған. Оның ішінде нанотұндыру және эмульсия әдістерінің полисүт қышқылы мен оның гликоль қышқылымен сополимерінің нанобөлшектері мен нанокапсулаларын синтездеуде болашағы зор екендігі көрсетілді. Полилактидгликолидтің наноөлшемді жүйелерін синтездеудің тағы бір әдісі қосарланған эмульсия әдісі болып табылады. Бұл әдіс ықшамды сипаттамаларға ие нанокапсулаларды алуға мүмкіндік береді. Аталған полимерлердің негізінде наносомалы жүйелерді қатерлі ісікке және түберкулезге қарсы дәрілік препараттармен иммобилизациялау мүмкіндігін қарастырды. Қатерлі ісік және туберкулез ауруларын емдеуде дәрілік заттармен иммобилизацияланған полисүт қышқылы мен полилактидгликолидті нанобөлшектері мен нанокапсулаларының медицинада қолданыс тапқан кейбір мысалдары келтірілген.
\end{abstract}

Кілm сөздер: полисүт қышқылы, полилактидгликолид, нанобөлшектер, қатерлі ісікке қарсы препараттар, туберкулезге қарсы препараттар, дәрілік заттарды жеткізу, полимерлер, нанокапсулалар.

\author{
Е.М. Тажбаев, М.Ж. Буркеев, Л.Ж. Жапарова, \\ Т.С. Жумагалиева, Ж.Т. Арыстанова
}

\section{Наночастицы на основе полимолочной кислоты и полилактидгликолида, иммобилизованные лекарственными препаратами}

\begin{abstract}
В статье приведен краткий обзор исследований, посвященных синтезу и изучению полимерных наночастиц и нанокапсул на основе полимолочной кислоты и ее сополимера с гликолевой кислотой. Наночастицы на основе биосовместимых и биодеградируемых полимеров молочной и гликолевой кислот привлекают внимание ученых при использовании их в качестве носителей лекарственных препаратов. В статье описаны методы синтеза наносомальных форм полилактида и полимолочной и гликолевой кислот. Методы наноосаждения и эмульсии показаны как перспективные способы получения полимерных наночастиц и нанокапсул полимолочной кислоты и ее сополимера с гликолевой кислотой для иммобилизации их лекарственными препаратами. Еще одним методом синтеза наноразмерных систем полилактид-со-гликолида является метод двойной эмульсии, который позволяет получить нанокапсулы с оптимальными характеристиками. Рассмотрены возможности иммобилизации наночастиц и нанокапсул на основе этих полимеров противоопухолевыми и противотуберкулезными препаратами. Показаны некоторые примеры наночастиц и нанокапсул полилактида и полимолочной и гликолевой кислот с лекарственными препаратами, которые уже нашли применение в медицине в лечении раковых заболеваний и туберкулеза.
\end{abstract}

Ключевые слова: полимолочная кислота, полилактидгликолид, наночастицы, противоопухолевые препараты, противотуберкулезные препараты, доставка лекарств, полимеры, нанокапсулы. 